\title{
Stavovi hrvatskih potrošača mesa prema proizvodima proizvedenima u skladu s dobrobiti životinja
}

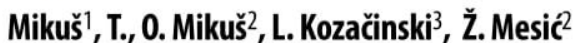

Originalni znanstveni rad

\section{SAŽETAK}

Procesi odlučivanja u kontekstu poljoprivredno-prehrambene politike i poljoprivredno-prehrambene industrije ne mogu biti dovršeni bez uključivanja stavova potrošača. Koncept uzgoja u skladu sa zahtjevima za dobrobit životinja u Hrvatskoj na početku je svog razvoja. Isto tako, ne postoji dovoljno informacija o stavovima hrvatskih potrošača mesa naspram takvog načina uzgoja i proizvoda proizvedenih u skladu sa zahtjevima za dobrobit životinja. Svrha ovog istraživanja bila je sakupiti informacije o ponašanju potrošača mesa pri kupnji crvenog mesa i testirati njihovo opće znanje o dobrobiti u uzgoju životinja. Potrošački stavovi prikupljeni su s pomoću polu-strukturiranog intervjua licem u lice, na uzorku od 187 potrošača, u mesnicama i na tržnicama. Dobiveni podaci analizirani su uni-varijantnom analizom i hi-kvadrat testom te uspoređeni s mnogobrojnim istraživanjima o dobrobiti životinja i time povezanim temama. Rezultati sugeriraju da spol ispitanika ima značajan utjecaj na mišljenje o dobrobiti životinja $(P<0,05)$, dok se imućniji ispitanici (s višim prihodom po kućanstvu) nalaze na granici značajnosti $(p=0,053)$ spremnosti na kupnju proizvoda u skladu sa zahtjevima za dobrobit životinja u budućnosti. Izvorni doprinos ovog istraživanja predstavlja utvrđivanje stavova hrvatskih kupaca prema proizvodima i proizvodnji u skladu sa zahtjevima za dobrobit životinja i njihovo poznavanje koncepta proizvodnje u skladu sa zahtjevima za dobrobit životinja.

Ključne riječi: stavovi potrošača, intervju, dobrobit životinja, crveno meso, Hrvatska
\end{abstract}

\section{UVOD}

Upravljanje sustavima uzgoja životinja i proizvodnje proizvoda životinjskog podrijetla zbog ubrzanog se razvoja i napretka ljudske civilizacije te sve veće potražnje za bjelančevinama životinjskog podrijetla tijekom posljednjih nekoliko desetljeća značajno promijenilo. S razvojem i promjenama u sustavima uzgoja životinja značajno je porasla i zabrinutost javnosti o dobrobiti životinja koje se upotrebljavaju u proizvodnji mesa (Harper i Makatouni, 2002.; Bornett i sur., 2003.; Mikuš i Petak 2010.; Mikuš i sur., 2011.; Spooner i sur., 2014.). Zabrinutost za dobrobit životinja temelji se na velikom broju znanstvenih istraživanja provedenih na temu dobrobiti životinja u uzgoju koja zaključuju da životinje osjećaju bol i strah (Sandoe i Simmonsen, 1992.; Stafleu i sur., 1996.; Sandoe i sur., 2003.; Grandin i Smith, 2004.).
Ipak, pri objašnjenju pojma „dobrobit životinja u uzgoju" često se zaboravlja da on ne prestaje važiti kad životinja dosegne određenu težinu ili dob i napusti farmu, nego bi se trebao primjenjivati i tijekom cijelog procesa transporta i klanja životinja. Stoga dobrobit životinja u uzgoju općenito, a posebice dobrobit životinja za vrijeme klanja, danas zauzima sve važniju ulogu u industriji proizvodnje mesa. Podizanje svijesti o kvaliteti hrane i dobrobiti životinja na poljoprivrednim gospodarstvima u EU-u je započelo krajem 1980-ih i početkom 1990-ih, istodobno s krizom Zajedničke poljoprivredne politike (ZPP) koja se bavila viškovima poljoprivrednih proizvoda. Od svog stupanja na snagu i primjene u zakonodavstvu 1962. godine, ZPP je prvenstveno usmjeren na proizvodnju, dok rješavanju problema zabrinutosti potrošača o statusu dobrobiti životinja i utjecaju poljo-

1 Tomislav Mikuš, dr. med. vet., Ured za dobrobit životinja Hrvatski veterinarski institut, Savska cesta 143, 10000 Zagreb, Hrvatska

2 doc. dr. sc. Ornella Mikuš, doc. dr. sc. Željka Mesić, Agronomski fakultet Sveučilišta u Zagrebu, Svetošimunska cesta 25, 10000 Zagreb, Hrvatska

3 prof. dr. sc. Lidija Kozačinski, Veterinarski fakultet Sveučilišta u Zagrebu, Heinzelova 55, 10000 Zagreb, Hrvatska 
privrede na okoliš općenito, nije pridavao mnogo pozornosti (Blokhuis i sur., 2003.). Sustavi za uzgoj životinja postajali su sve intenzivniji, životinje su zbog lakše uporabe profilaktičkih lijekova i promotora rasta premještene u sustave zatvorenih pogna za uzgoj, a kako su se sa smanjenjem broja povećale veličina i kapacitet klaonica, a time i njihova udaljenost, transport životinja na kraju proizvodnog ciklusa postao je sve dugotrajniji (Fraser, 2003.; Sandoe i sur., 2003.; Winter i sur., 1998.; Boogard i sur., 2011.a). Povećanje intenziteta uzgoja životinja možemo pratiti na više razina. Tako se, na primjer, drastično smanjio udio stočara, iako se povećao broj životinja po farmi (Blokhuis i sur., 2003.). Osim toga, kriza ZPP-a zbog nekoliko se afera vezanih uz sigurnost hrane ("uzbuna povezanih s hranom"), poput razorne goveđe spongiformne encefalopatije povezane sa smrtonosnom bolesti ljudskog mozga (Creutzfeldt-Jakobova bolest), salmonele u jajima, benzena u bocama vode za piće Perrier itd., još više produbila. Ovo je tek nekoliko od brojnih uzbuna povezanih s hranom koje su potrošače nagnale da preispitaju način proizvodnje hrane (Winter i sur., 1998.; Knowless, 2007.).

Zabrinutost povezana $s$ hranom opisana je $u$ brojnim ispitivanjima stavova potrošača provedenim 1990in godina (Bennet, 1996., 1997., 1998.). Činjenica da su potrošači negativno ocjenjivali razvoj intenzivnog uzgoja životinja (Gade, 2002.) uzrokovala je promjenu tradicionalnog pristupa sigurnosti hrane iz "od farme do vilice" u "od vilice do farme“. Budući da takav „od vilice do farme" pristup u obzir uzima interese potrošača i integrira njihove potrebe za kvalitetom i većom sigurnošću hrane (Busquin, 2004.; Mayfield i sur., 2007.), prouzrokovao je usvajanje novih zakona tijekom posljednjih nekoliko godina (Bornett, 2003.; Moynagh, 2000.).

Europska unija (EU) usvojila je Akcijski plan za zaštitu i dobrobit životinja (Službeni list EU-a od 28. veljače 2006.), koji je kasnije nadopunjen Strategijom za zaštitu i dobrobiti životinja EU-a za razdoblje od 2012. do 2015. godine (Glavna uprava Europske komisije za zdravlje i sigurnost hrane, 2012.) te Uredbom o dobrobiti životinja za vrijeme klanja (Službeni list EU-a od 18. studenog 2009.). Ti dokumenti preporučuju i upućuju poljoprivrednike na način uzgoja i klanja stoke koji joj osigurava najnižu moguću razinu stresa. lako bi zakonodavstvo o dobrobiti životinja trebalo osigurati učinkovito jamstvo kvalitete proizvoda, potrošači dobrobit životinja povezuju s percepcijom visoke kvalitete i brandovima, pri čemu percepciju kvalitete dodatno povećavaju i visoke cijene (Ingelbleek i Immink, 2011.). Kako bi se mesu odobrilo plasiranje na tržište pod određenom oznakom (brandom), oznaka treba naglasiti i kako su životinje uzgajane te kako se s njima rukovalo. Postojanje povezanih certifikata dokazuje da su potrošači diljem EU-a spremni platiti više za meso i proizvode od mesa dobivene od životinja uzgojenih u sustavima usklađenim sa zahtjevima za dobrobit životinja.

Hrvatski sustav sigurnosti hrane, zbog obveza članstva, danas je usklađen sa propisima EU-u. lako je Hrvatska imala relativno dobro razvijen sustav kontrole hrane i prije ulaska u EU, nije postojao jedinstven multiinstitucionalni pristup koji bi definirao zajedničke ciljeve, akcijske planove i uvjete njihovog postizanja. Tijekom razdoblja pregovora, Hrvatska je pristupila novom načinu stvaranja sustava sigurnosti hrane koji je usmjeren na potrošače, a temelji se na suvremenim alatima za analizu rizika (Antunović i sur., 2006.; Antunović i sur., 2008.).

Prvo preliminarno znanstveno istraživanje o stavovima potrošača prema proizvodima proizvedenim u sustavima usklađenim sa zahtjevima za dobrobit životinja provedeno u Hrvatskoj izvršili su Cerjak i sur. 2011. godine. Njihovo istraživanje pokazalo je da više od polovice hrvatskih potrošača pri kupnji mesa i mesnih proizvoda ne uzima u obzir dobrobit životinja. Ti su rezultati slični rezultatima Eurobarometrovog ispitivanja iz 2007. (EK, 2007.) i 2015. godine (EK, 2015.). Ostović i sur. su 2015. godine proveli ispitivanje hrvatskih studenata veterine kako bi utvrdili utječe li slušanje kolegija o dobrobiti životinja na razinu empatije prema životinjama u uzgoju. Rezultati su, nažalost, pokazali nižu razinu suosjećanja za životinje u uzgoju nakon pohađanja kolegija o dobrobiti životinja (Ostović i sur., 2015.).

Cilj je ovog istraživanja bio utvrditi stavove i obrasce ponašanja hrvatskih potrošača prema kupovini crvenog mesa proizvedenog u sustavima usklađenim sa zahtjevima za dobrobit životinja, što u kontekstu potražnje proizvoda od crvenog mesa na tržištu, prehrambenoj industriji pruža vrlo korisnu povratnu informaciju. Rezultati ujedno odražavaju znanje i svijest potrošača o dobrobiti životinja u uzgoju, važnima za donošenje učinkovitih mjera državnih politika u poljoprivredi i prehrambenoj industriji te alata za poboljšanje standarda proizvodnje mesa i prijenosa znanja potrošačima.

\section{MATERIJAL I METODE}

Proveli smo polu-strukturirani intervju lice u lice sa 187 potrošača mesa različitih demografskih skupina, poput dobi, spola i stupnja obrazovanja te društvene i ekonomske pozadine. Istraživanje je provedeno u mesnicama i tržnicama, a ispitanici su bili u procesu kupnje crvenog mesa ili proizvoda od crvenog mesa (ciljano uzorkovanje). Intervjuirani su samo oni posjetitelji koji su bili spremni sudjelovati $u$ istraživanju, a na temelju broja ljudi koji su odbili sudjelovati nije moguće izračunati stopu odgovora. Ispitivanje je provođeno u razdoblju od tri mjeseca, od listopada 2012. do siječnja 2013. godine. Kako bismo ispravili moguće nejasnoće u tekstu 
i redoslijedu pitanja, upitnik je, prije ispitivanja na terenu, testiran na uzorku od 20 ispitanika.

Upitnik se sastojao od ukupno 23 pitanja zatvorenog i otvorenog tipa, a obuhvaćao je stavove i znanje o dobrobiti životinja, važnost pojedinih značajki dobrobiti životinja, osobno mišljenje o položaju dobrobiti životinja u Hrvatskoj te spremnost na plaćanje dodane vrijednosti za hranu životinjskog podrijetla usklađenu sa zahtjevima za dobrobit životinja. Prikupljeni su socioekonomski podaci o dobi, spolu, stupnju obrazovanja i ekonomskom statusu potrošača.

Stavovi potrošača prema dobrobiti životinja mjereni su skupom čestica koji je sačinjavalo 10 tvrdnji. Tvrdnje su preuzete su iz literature (Heleski i sur., 2004.; Frewer i sur., 2005.; Tawse, 2010.; Cerjak i sur., 2011.) i prilagođene ovom istraživanju. Od ispitanika je zatraženo da ponuđene tvrdnje ocijene na Likertovoj ljestvici od 1 do 5 , pri čemu se ocjena 1 odnosila na potpuno neslaganje, a 5 označavalo da se ispitanik u potpunosti slaže s određenom tvrdnjom.

Podaci prikupljeni ispitivanjem analizirani su s pomoću Statističkog paketa za društvene znanosti (engl. Statistical Package for Social Sciences, SPSS), inačica 17.0. Učestalost odgovora potrošača analizirana je univarijantnom analizom. Razlike između različitih demografskih skupina potrošača utvrđene su križanjem dobivenih odgovora i određivanjem njihove međusobne ovisnosti, odnosno cross-tabulation analizom, dok je njihova značajnost testirana primjenom X2-testa. Pokazatelji stavova potrošača istraženi su izračunavanjem srednjih vrijednosti odgovora na skalama stavova. Kvantitativni rezultati tumačeni su i uspoređeni s nalazima ostalih istraživanja povezanih s proizvodnjom usklađenom sa zahtjevima za dobrobit životinja, povezanim politikama i ponašanjem potrošača.

\section{REZULTATI}

Osnovne socioekonomske značajke uzorka prikazane su u tablici 1. $\mathrm{U}$ istraživanju je sudjelovalo ukupno 187 ispi-

Tablica 1. Socioekonomske značajke uzorka istraživanja

\begin{tabular}{|l|l|l|}
\hline & & $100 \%$ \\
\hline \multirow{3}{*}{ Spol } & Muški & 45.5 \\
& Ženski & 54.5 \\
\hline \multirow{5}{*}{ Dobna skupina (godine) } & $18-25$ & 30.0 \\
\hline & $26-35$ & 33.0 \\
\hline \multirow{5}{*}{ Stupanj obrazovanja } & $36-50$ & 23.0 \\
\hline & $50+$ & 15.0 \\
\hline \multirow{5}{*}{ Prihod po kućanstvu } & Osnovna škola & 5.0 \\
\hline & Srednja škola & 64.0 \\
\hline & Sveučlišna diploma & 31.0 \\
\hline & Niski prihod & 14.0 \\
\hline & Srednji prihod & 27.0 \\
\hline & Viši prihod & 31.0 \\
\hline & Visoki prihod & 28.0 \\
\hline
\end{tabular}

tanika. Uzorak je obuhvatio 54,5 \% ženskih i 45,5 \% muških ispitanika prosječne dobi od 46 godina. Otprilike 63 $\%$ potrošača bilo je mlađe od 35 godina. Više od polovice ispitanika završilo je srednju školu, od čega ih je 31 $\%$ steklo sveučilišnu diplomu. Samo je $14 \%$ potrošača imalo niske mjesečne prihode (do 400 EUR) (tablica 1.).

Više od polovice ispitanika bilo je upoznato $s$ konceptom dobrobiti životinja za vrijeme klanja (63\%), pri čemu je taj koncept najčešće povezivan sa skrbi i humanim postupanjem za vrijeme uzgoja i transporta životinja. Od ukupnog broja ispitanika koji su bili upoznati s konceptom dobrobiti životinja za vrijeme klanja, njih se $42 \%$ izjasnilo da kupuje proizvode iz sustava uzgoja životinja u skladu sa zahtjevima za dobrobit životinja. Između takvih proizvoda, potrošači su najčešće kupovali svježe meso i mesne proizvode (a navodili su i jaja te mlijeko). Više od polovice ispitanika ( $55 \%$ ) vjeruje da je pri kupnji mesa osjetna razlika u kvaliteti između mesa proizvedenog u sustavima usklađenim sa zahtjevima za dobrobit životinja i mesa proizvedenog na uobičajen način, dok jedna trećina ( $33 \%$ ) nije mogla procijeniti razliku. Ispitanici su vjerovali da je meso proizvedeno u sustavima usklađenim sa zahtjevima za dobrobit životinja bolje kvalitete i okusa, odnosno da su životinje uzgajane u humanim uvjetima manje izložene stresu te da konzumiraju zdraviju hranu (tablica 2.).

Tablica 2. Prehrambene navike i ponašanje u kupnji te mišljenje potrošača 0 dobrobiti životinja

\begin{tabular}{|c|c|c|}
\hline & & $100 \%$ \\
\hline \multirow{2}{*}{$\begin{array}{l}\text { Jeste li upoznati s konceptom do- } \\
\text { brobiti životinja za vrijeme klanja? }\end{array}$} & $\mathrm{Da}$ & 62.6 \\
\hline & $\mathrm{Ne}$ & 37.4 \\
\hline \multirow{3}{*}{$\begin{array}{l}\text { Kupujete li proizvode proizvedene } \\
\text { u skladu sa zahtjevima za dobrobit } \\
\text { životinja? }\end{array}$} & $\mathrm{Da}$ & 42.2 \\
\hline & $\mathrm{Ne}$ & 39.0 \\
\hline & Ne znam & 18.7 \\
\hline \multirow{3}{*}{$\begin{array}{l}\text { Postoji li razlika između mesa proi- } \\
\text { zvedenog u skladu sa zahtjevima za } \\
\text { dobrobit životinja i mesa proizvede- } \\
\text { nog na uobičajen način? }\end{array}$} & $\mathrm{Da}$ & 55.1 \\
\hline & $\mathrm{Ne}$ & 11.8 \\
\hline & Ne znam & 33.2 \\
\hline
\end{tabular}

Osim dobrobiti za vrijeme klanja, ispitanici su također smatrali da je vrlo važno (43\%), odnosno važno (42 $\%)$, obratiti pozornost na dobrobit životinja na poljoprivrednim gospodarstvima. Samo je $15 \%$ ispitanika smatralo da to nije ni važno ni nevažno. Rezultati pokazuju da ženske osobe dobrobit životinja na farmama smatraju mnogo važnijom nego muške osobe $(p<0,05)$.

Tablica 3. prikazuje kako su ispitanici ocijenili pojedine čimbenike dobrobiti životinja: uvijek dostupna voda i hrana za životinje (srednja vrijednost 4,82), kvaliteta stočne hrane (srednja vrijednost 4,68), mogućnost slobodnog kretanja životinja (srednja vrijednost 4,57 ) i mogućnost pristupa životinja prirodnom svjetlu (srednja vrijednost 4,56 ). lako su preostali izvori zabrinuto- 
sti, poput uvjeta za vrijeme transporta i u klaonicama, ocijenjeni nižim ocjenama, još se uvijek nalaze u gornjoj polovici Likertove ljestvice. Najnižu ocjenu dobilo je pitanje o sakaćenju životinja (srednja vrijednost 3,91).

Tablica 3. Ocjena potrošača o važnosti različitih čimbenika dobrobiti životinja

\begin{tabular}{|l|l|l|}
\hline Čimbenik & Srednja vrijednost & Standardna devijacija \\
\hline Mogućnost slobodnog kretanja na farmi & 4.57 & 0.67 \\
\hline Dostupnost hrane i vode na farmi & 4.82 & 0.41 \\
\hline Kvaliteta stočne hrane na farmi & 4.68 & 0.57 \\
\hline Prirodno svjetlo na farmi & 4.56 & 0.68 \\
\hline Mogućnost prirodnog ponašanja životinja & 4.11 & 0.90 \\
\hline Sakaćenje životinja (kastracija, brušenje zubi itd.) & 3.91 & 1.12 \\
\hline Uvjeti transporta & 4.36 & 0.79 \\
\hline Pristup otvorenom prostoru u sklopu klaonice & 4.44 & 0.78 \\
\hline Uvjeti klanja & 4.46 & 0.81 \\
\hline Prisutnost stručnog osoblja u klaonici & 4.40 & 0.87 \\
\hline
\end{tabular}

Kao što je prikazano u tablici 4., najveći broj ispitanika smatra da potrošači trebaju više informacija o dobrobiti životinja (srednja vrijednost 4,66). Veliki broj ispitanika također smatra da je društvo moralno obvezno pridržavati se visokih standarda za dobrobit životinja (srednja vrijednost 4.24), a da svatko treba razmisliti o patnji životinja $(4,18)$. S druge strane, ispitanici su dobrobit u klaonicama smatrali vrlo važnim pitanjem, a preferiraju meso dobiveno od životinja uzgajanih u sustavima koji su usklađeni sa zahtjevima za dobrobit životinja (srednja vrijednost 3,75 ). Ispitanici su tvrdnju da nije važno kako su životinje uzgajane jer nisu upoznate s boljim, ocijenili negativno (srednja vrijednost 1,61).

Tablica 4 Stavovi potrošača o dobrobiti životinja na poljoprivrednim gospodarstvima

\begin{tabular}{|l|l|l|}
\hline Tvrdnja & $\begin{array}{l}\text { Srednja } \\
\text { vrijed- } \\
\text { nost }\end{array}$ & $\begin{array}{l}\text { Standardna } \\
\text { devijacija }\end{array}$ \\
\hline Radije jedem meso životinja za koje znam da su bile dobro tretirane & 3.75 & 0.95 \\
\hline Okus mesa važniji je od načina uzgoja životinja & 2.76 & 1.32 \\
\hline Patnja životinja treba biti briga svih ljudi & 4.18 & 1.05 \\
\hline Nije važno kako su životinje uzgajane jer nisu upoznate s boljim & 1.61 & 0.92 \\
\hline Životinjama na farmama treba se omogućiti prirodno ponašanje & 4.11 & 0.88 \\
\hline Kućni ljubimce zaslužuju bolji tretman od životinja na farmama & 2.38 & 1.24 \\
\hline $\begin{array}{l}\text { Društvo ima moralnu obvezu pridržavati se visokih standarda za } \\
\text { dobrobit životinja }\end{array}$ & 4.24 & 0.82 \\
\hline Volio bih da se potrošače više informira o pitanjima dobrobiti životinja & 4.66 & 2.98 \\
\hline
\end{tabular}

Od potrošača je zatraženo da procijene vjerojatnost kupnje proizvoda u skladu sa zahtjevima za dobrobit životinja u budućnosti. Rezultati su pokazali da će približno polovica ispitanika (51,3\%) vjerojatno ili vrlo vjerojatno kupovati proizvode u skladu sa zahtjevima za dobrobit životinja, dok je za $13,9 \%$ ispitanika to bilo malo ili uopće nije bilo vjerojatno. Jedna trećina sudionika ispitivanja nije bila sigurna o vlastitom ponašanju po- vezanom s kupnjom proizvoda u skladu sa zahtjevima za dobrobit životinja u budućnosti.

Što se tiče spremnosti potrošača da za proizvode u skladu sa zahtjevima za dobrobit životinja plate višu cijenu, veliki broj ispitanika (71 \%) bio je spreman platiti više za mesne proizvode usklađene sa zahtjevima za dobrobit životinja. Za gotovo jednu trećinu $(31,5 \%)$ tih potrošača, prihvatljiva dodatna cijena koju su bili spremni platiti iznosila je do $10 \%$, njih $13 \%$ bilo je spremno platiti cijenu višu za $15 \%$ do $20 \%$, dok je njih $25 \%$ za proizvode u skladu sa zahtjevima za dobrobit životinja bilo spremno izdvojiti više od $20 \%$ (slika 1.). Rezultati ukazuju da viši prihod kućanstva gotovo ne utječe na kupnju proizvoda u skladu sa zahtjevima za dobrobit životinja.

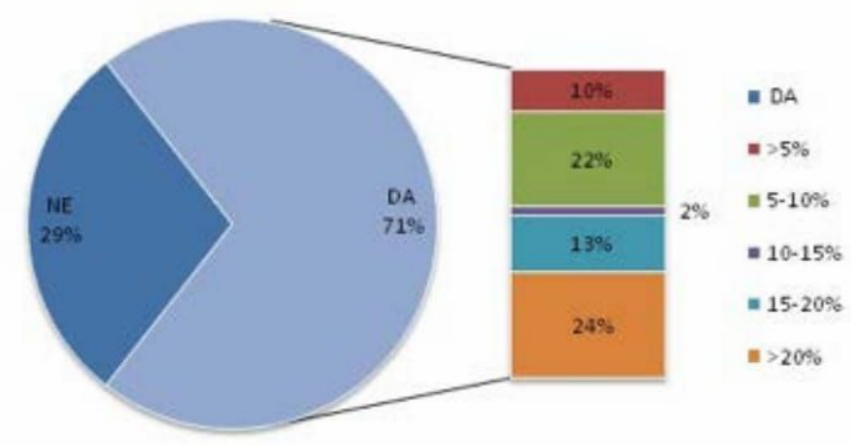

Slika 1. Spremnost potrošača da za proizvode usklađene sa zahtjevima za dobrobit životinja plate višu cijenu

Više od polovice ispitanika (52 \%) smatra da su u posljednjem desetljeću uvjeti povezani s dobrobiti životinja u Hrvatskoj ostali nepromijenjeni, dok $40 \%$ ispitanika smatra da su ti uvjeti poboljšani. Samo $8 \%$ ispitanika smatra da su se uvjeti povezani s dobrobiti životinja u Hrvatskoj pogoršali.

\section{RASPRAVA}

Ovim smo ispitivanjem nastojali istražiti mišljenja i stavove hrvatskih potrošača mesa. Zbog toga je provedeno na odabranim mjestima poput mesnica i tržnica. Isto tako, budući da smo htjeli biti sigurni da su naši ispitanici upravo one osobe od kojih smo željeli prikupiti podatke, za ovu smo konkretnu studiju odlučili upotrijebiti intervju licem u lice i ciljano uzorkovanje (umjesto telefonskog ili internetskog istraživanja).

Općenito govoreći, naši rezultati pokazuju veliko podudaranje $s$ rezultatima ostalih istraživanja provedenih u EU-u tijekom posljednjeg desetljeća, a ukazuju da hrvatski potrošači izražavaju visoku razinu empatije prema životinjama u uzgoju. Potrošači pokazuju zabrinutost zbog: a) prirodnih uvjeta na farmi poput pristupa prirodnom svjetlu i otvorenom prostoru (dvorište), dostupnosti i kvaliteti hrane te vode (Ellis i sur., 2009.; 
Boogard i sur., 2008.; Krystallis i sur., 2009.), ali i mogućnost prirodnog ponašanja i slobodnog kretanja životinja (Evans i Miele, 2007., Veissier i sur., 2011.), b) sakaćenja i boli povezane sa suvremenim metodama proizvodnje (Boogard i sur., 2011.b; Miele i sur., 2011.), c) upravljanja životinjama i načina na koji se životinje uzgajaju (Boogard i sur., 2008.; Boogard i sur., 2011.b; Ellis i sur., 2009.), d) uvjeta za vrijeme transporta i klanja te prisustva stručnog osoblja za vrijeme klanja (Miele i Evans, 2005.).

Važno je napomenuti da su potrošači izrazili vrlo visoku razinu zabrinutosti u svezi s moralnom obvezom društva da ispunjava zahtjeve za dobrobit životinja, koju prati i visoka razina zabrinutosti pojedinaca. To ukazuje da hrvatski potrošači postaju sve više svjesni vlastite uloge u lancu proizvodnje mesa. Kako u EU-u postoji tendencija da se odgovornost za pridržavanje standarda za dobrobit životinja s potrošača prenese na poljoprivrednke, naš se rezultat nešto razlikuje od rezultata ispitivanja europskih potrošača (Glavna uprava Europske komisije za zdravlje i sigurnost hrane i Glavna uprava Europske komisije za komunikacije, 2007.).

Prikupljeni podaci pokazuju da je, slično prethodnom istraživanju provedenom u Hrvatskoj (Cerjak i sur., 2011.), velika većina ispitanika izrazila veliku zabrinutost za dobrobit životinja, što je u skladu s mišljenjem koje prevladava u EU-u (Glavna uprava Europske komisije za zdravlje i sigurnost hrane i Glavna uprava Europske komisije za komunikacije, 2007.; Mayfield i sur., 2007.; Glavna uprava Europske komisije za zdravlje i sigurnost hrane i Glavna uprava Europske komisije za komunikacije, 2015.). Međutim, iako su ispitanici pokazali veliku zabrinutost zbog dobrobiti životinja, većina ih dobrobit životinja ne uzima u obzir pri kupnji mesa, što je slično drugim europskim potrošačima, pri čemu hrvatski potrošači često miješaju pojam „dobrobit životinja” s drugim sličnim oznakama poput "bio“ i "eko" (Napolitano i sur., 2010.; Boogard i sur., 2011.b; Spooner i sur., 2014.).

Visoki se postotak od više od $70 \%$ potrošača koji su tijekom ispitivanja izrazili spremnost platiti višu cijenu za proizvode u skladu sa zahtjevima za dobrobit životinja može činiti iznenađujućim, no on je u potpunosti u skladu s mišljenjem većine građana EU-a, kao i sudionika prethodnog istraživanja o dobrobiti životinja provedenog u Hrvatskoj (Glavna uprava Europske komisije za zdravlje i sigurnost hrane i Glavna uprava Europske komisije za komunikacije, 2007.; Cerjak i sur., 2011.). Spremnost ispitanika iz kućanstava s višim prihodima da plate više za proizvode u skladu sa zahtjevima za dobrobit životinja na granici je statističke značajnosti ( $p=0,053)$, no kada pobliže promotrimo spremnost potrošača da plate višu cijenu, gotovo je četvrtina ispitanika izrazila spremnost platiti do $20 \%$ više, dok bi $45 \%$ ispitanika za takve proizvode bilo spremno platiti do, pa i preko $20 \%$ višu cijenu.
Ti su postoci nešto veći od onih koje je zabilježio Cerjak 2011. godine (oko četvrtine ispitanika platilo bi do 50 $\%$ više, a tri četvrtine do $20 \%$ više za takve proizvode), što bi se moglo objasniti činjenicom da je Cerjak 2011. godine ispitivanje provodio na sajmu tradicionalnih proizvoda čiji posjetitelji pridaju veću važnost poštivanju tradicionalnog načina proizvodnje u kojem je kvaliteta uvijek prva. Unatoč tomu, budući da je samo relativno mali dio potrošača smatrao da u budućnosti neće kupovati proizvode u skladu sa zahtjevima za dobrobit životinja, dobiveni se rezultati mogu smatrati ohrabrujućim za prehrambenu industriju. Ističemo i relativno velik dio neodlučanih potrošača koji bi pod utjecajem obrazovanja i oglašavanja mogli početi kupovati proizvode usklađene sa zahtjevima za dobrobit životinja, a upravo je to smjer koji bi prehrambena industrija u Hrvatskoj trebala uzeti u budućnosti. Takvi bi sustavi trebali postati iznimno važni i za hrvatske proizvođače mesa, posebeice kada u obzir uzmemo da bi $86 \%$ naših ispitanika u budućnosti vjerojatno kupovalo proizvode u skladu sa zahtjevima za dobrobit životinja. Štoviše, konkurentnost tvrtki mogla bi se ojačati ciljanjem tržišnih segmenata potrošača koji zahtijevaju proizvode u skladu s višim standardima za dobrobit životinja (Keeling i sur., 2012.).

Većina ispitanika (52 \%) vjeruje da se u posljednjem desetljeću poboljšalo pridržavanje zahtjeva koji se odnose na dobrobit životinja na poljoprivrednim gospodarstvima, što se može objasniti utjecajem velikih javnih kampanji koje su u Hrvatskoj provodile velike nevladine udruge za dobrobit životinja i podizanjem svijesti o stanju dobrobiti životinja u Hrvatskoj raznim instrumentima poljoprivredne i ostalih politika (podrška u edukaciji sudionika u lancu hrane te istraživanju i razvoju). Osim toga, poljoprivrednici pokazuju sve više zanimanja i motivacije za državne i, posebice, ZPP potpore financirane sredstvima Europskog poljoprivrednog fonda za ruralni razvoj (engl. European Agricultural and Rural Development Fund, EARDF) koje nastoje nadoknaditi troškove koji proizlaze iz provedbe viših standarda za dobrobit životinja. Nadalje, proizvođači na svojim proizvodima sve više oglašavaju humani način proizvodnje (npr. oznaka "meso s hrvatskih pašnjaka"). U državama gdje dobrobit životinja predstavlja neizravan ili sekundarni motiv potrošača, moguće je ojačati odnos između dobrobiti životinja i drugih motiva za kupnju poput oznaka kvalitete ili izvornog podrijetla (Keeling i sur., 2012.).

Prema Mayfieldovom istraživanju iz 2001. godine, potrošači iz EU-a vjeruju da je u posljednjem desetljeću poboljšano pridržavanje zahtjeva za dobrobit životinja (Italija 59 \%, Velika Britanija 55 \%, Švedska 68 \%), što je u skladu s Eurobarometrovim istraživanjem iz 2007. godine prema kojem taj postotak iznosi 51 \%. Kako je oko trećine ispitanika u istraživanju koje su 2011. godi- 
ne proveli Cerjak i sur. vjerovalo da se zaštita dobrobiti životinja na farmama u Hrvatskoj u posljednjem desetljeću poboljšala, naši su rezultati, uz jednu iznimku, usporedivi s prethodnim istraživanjima - naime u našem je istraživanju samo $8 \%$ ispitanika smatralo da je pridržavanje zahtjeva za dobrobit životinja lošije nego prije. Taj je rezultat u potpunosti drugačiji od istraživanja Cerjaka i sur. iz 2011. godine u kojem je čak $44 \%$ ispitanika smatralo da je trenutačna razina pridržavanja zahtjeva za dobrobit životinja lošija. To se može objasniti manjom veličinom uzorka u njihovom istraživanju, kao i već spomenutom činjenicom da je njihovo ispitivanje uključivalo jedinstvenu populaciju (posjetitelje na sajmu tradicionalnih proizvoda). Naime, kupci tradicionalnih proizvoda pridaju veću važnost poštivanju tradicionalnog načina proizvodnje mesa.

Od socioekonomskih značajki potrošača u našem istraživanju, samo je za spol utvrđena istinska statistička značajnost, dok za dob, stupanj obrazovanja i prebivalište ispitanika (ruralno nasuprot urbanog stanovništva) značajnost nije utvrđena. Ženske su osobe izrazile veću zabrinutost $(P<0,05)$ za dobrobit životinja na farmama nego muške osobe, što je u korelaciji s drugim istraživanjima koja su u ispitivanje stavova o dobrobiti životinja uključila pitanje o spolu ispitanika (Paul i Podberscek, 2000.; Serpell, 2005.; Hazel i sur., 2011.; Van der Weijden, 2013.; Pollard-Williams i sur., 2014.). Walker, 2014., kao razlog tomu, navodi da je mozak muških osoba uglavnom predodređen da "sistematizira" informacije, odnosno analizira, istražuje i nastoji razumjeti sustave, a da je, s druge strane, mozak ženskih osoba uglavnom predodređen za "empatiju“, odnosno sposobnost razumijevanja vlastitih i tuđih osjećaja te emotivno prikladan odgovor na tuđe osjećaje. Pozitivniji stavovi ženskih osoba prema dobrobiti životinja u odnosu na muške osobe mogu biti povezani i s reakcijom suosjećanja koju ženske osobe osjećaju kada vjeruju da će životinje osjetiti neku vrstu boli ili neugode (Knight i sur., 2003.). Stoga su, budući da su predodređene osjećati empatiju prema drugima, ženske osobe sklonije pripisivati osjećaje životinjama (Knight i sur., 2004.).

\section{ZAKLJUČCI}

Ovo je, do danas, najveće istraživanje licem u lice provedeno o svijesti potrošača o pitanjima dobrobiti životinja u Hrvatskoj. Mišljenja ispitanika o dobrobiti uzgajanih životinja u klaonicama uglavnom su bila pod utjecajem spola (ženske osobe bile su značajnije $(p<0,05)$ osjetljivije na ponašanje prema životinjama, uključujući životinje na farmama). lako su dobna skupina i stupanj obrazovanja imali znatan utjecaj na mišljenje potrošača, za njih nije utvrđena značajnost. Sudionike istraživanja zanimalo je jesu li životinje bile tretirane u skladu sa standar- dima za dobrobit životinja tijekom uzgoja, transporta i klanja, a izražen je i velik interes za primjenu humanih metoda. Rezultati su pokazali da je većina potrošača zabrinuta zbog dobrobiti životinja. Međutim, u segmentu neodlučnih potrošača i potrošača koji još uvijek nisu svjesni učinka dobrobiti životinja na kvalitetu mesa, postoji prostor za poboljšanje. Ispitanici su zapravo sami prepoznali potrebu za boljim informiranjem hrvatskih potrošača u svezi dobrobiti životinja na farmama i u objektima za klanje, kao i o tome kako ostvarenje različitih razina dobrobiti životinja utječe na kvalitetu mesa.

Veličina i postupak ciljanog uzorkovanja u ovom istraživanju omogućili su donošenje zaključaka o hrvatskim potrošačima mesa i njihovim stavovima prema dobrobiti životinja. Hrvatski potrošači sve su više zainteresirani i svjesniji utjecaja dobrobiti životinja na kvalitetu mesa, a povećana je i potražnja za transparentnošću u načinu procjene i upravljanja ovom problematikom od javnog interesa. Općenito govoreći, potrošači žele znati kako se hrana proizvodi i podrijetlo mesa koje konzumiraju pa na temelju dobivenih informacija odlučuju što će kupiti i koliko su to spremni platiti.

Buduća istraživanja trebala bi obuhvatiti stavove potrošača prema različitim sustavima i metodama uzgoja životinja, kao i procjenu učinkovitosti pridržavanja zahtjeva za osiguranje dobrobiti životinja na poljoprivrednim gospodarstvima. Stoga postoji objektivna potreba ovakva istraživanja ponoviti na većem uzorku i većoj distribuciji ispitanika u svim hrvatskim regijama.

\section{LITERATURA}

Antunović, B., G. Kralik, B. Njari (2006): Establishing new food safety approach in EU accessing countries - Croatian challenges and opportunities Acta Agraria Caposvariensis, 10 (2), 7-17.Available at: https://www.cabdirect.org/cabdirect/abstract/20093275847

Antunović, B., K. Mancuso, K. Capak, V. Poljak, T. Florijančić (2008): Background to the preparation of the Croatian Food Safety Strategy. Food Control 19 (11), 1017-1022.http://doi. org/10.1016/j.foodcont.2007.10.012

Blokhuish, J., R. B. Jones., R. Geers, M. Miele, I. Veissier (2003): Measuring and monitoring animal welfare: transparency in the food product quality chain. Animal Welfare 12 (4), 445-455. Available at: http://s3.amazonaws.com/academia.edu.documents/37050103/Measuring_and_Monitoring_Animal_Welfare_Blokhuis_et_al_2003.pd?AWSAccessKeyld=AKIAIW OWYYGZ2Y53UL3A\&Expires $=1491569122 \&$ Signature $=\$ 5$ dQwjyrRH $\% 2 F R h V V O B \% 2 F j x Q m A Q b$ C4\%3D\&response-content-disposition=inline\%3B\%20filename\%3DMeasuring_and_monitoring_animal_welfare.pdf

Bennett, R. M. (1996): People's willingness to pay for farm animal welfare. Animal Welfare 5(1), 3-11.

Bennet, R. M. (1997): Farm animal welfare and food policy. Food Policy 22 (4), 281-288. https://doi.org/10.1016/S0306-9192(97)00019-5

Bennett, R. M. (1998): Measuring public support for animal welfare legislation: a case study of cage egg production. Animal Welfare 7 (1), 1-10.

Boogaard, B. K., S.J. Oosting, B. B. Bock (2008): Defining sustainability as a socio cultural 
concept: citizen panels visiting dairy farms in the Netherlands. Livest. Sci.117 (1),24-33.http://doi. org/10.1016/j.livsci.2007.11.004

Boogaard, B. K., B. B. Bock, S. J. Oosting, J. S. C. Wiskerke, A. Van der Zijpp (2011a): Social acceptance of dairy farming: the ambivalence between the two faces of modernity. J Agric Environ Ethics 24 (3), 259-282.doi: 10.1007/s10806-010-9256-4

Boogaard, B. K., L. J. S. Boekhorst, S. J. 0osting, J. T. Sorensen, J. T. (2011b): Sociocultural sustainability of pig production: citizen perceptions in the Netherlands and Denmark. Livest. Sci.140 (1-3),189-200. http://doi.org/10.1016/j.livsci.2011.03.028

Bornett, H. L. I., J. H. Guy, P.J. Cain (2003): Impact of animal welfare on costs and viability of pig production in the UK. Journal of Agricultural and Environmental Ethics16 (2), 163-186.doi: 10.1023/A:1022994131594

Busquin, P. (2004): From fork-to-farm a new approach to European agro-food research. FS (Food Safety) European edition. Available at: http://www.gdspublishing.com/ic

Cerjak, M., D. Karoly, Ž. Mesić (2011): Consumers'attitudes towards farm animal welfare and their influence on meat consumption. Agriculturae Conspectus Scientificus 76 (4), 283-286. Available at: http://www.agr.unizg.hr/smotra/pdf_76/acs76_54.pdf

European Commission Directorate-General for Health and Food Safety (EC DG SANTE) (2012). Communication from the Commission to the European Parliament, the Council and the European Economic and Social Committee on the European Union Strategy for the Protection and Welfare of Animals 2012-2015, Brussels. Available at: http://ec.europa.eu/food/animals/docs/ aw_eu_strategy_19012012_en.pdf

European Commission Directorate-General for Health and Food Safety and Directorate-General for Communication (ECDG SANTE and DG COMM) (2007). Attitudes of EU citizens towards animal welfare. Special Eurobarometer 270th Report pp 1-51. EC: Brussels. Available in: http://ec.europa.eu/public_opinion/archives/ebs/ebs_270_en.pdf

European Commission Directorate-General for Health and Food Safety and Directorate-General for Communication (ECDG SANTE and DG COMM) (2015). Attitudes of Europeans towards Animal Welfare animal welfare. Special Eurobarometer 442nd Report pp 1-60. EC Brussels. Available at: http://ec.europa.eu/COMMFrontOffice/PublicOpinion/index.ffm/ResultDoc download/DocumentKy/71348

Ellis, K. A., K. Billington, B. Mcneil, B. Mckeegan (2009): Consumer perceptions of dairy welfare and production: a role for vets in public education? Cattle Practice 17 (2),148-152. Available at: http://eprints.gla.ac.uk/36066/

Evans, A., M. Miele (2007): Consumers' Views about Farm Animal Welfare: Part I. Welfare Quality Report Number 4. Cardiff University Press, Cardiff,UK.

Fraser, D. (2003): Assessing animal welfare at the farm and group level: the interplay of science and values. Animal Welfare 12:433-443.

Frewer, L.J., A. Kole, S. M. A. Van de Kroon, C. De Lauwere (2005): Consumer attitudes towards the development of animal-friendly husbandry systems. Journal of Agricultural and Environmental Ethics 18(4),345-367. doi: 10.1007/s10806-005-1489-2

Gade, P. B. (2002): Welfare of animal production in intensive and organic systems with special reference to Danish organic pig production. Meat Science 62: 353-358. http://doi.org/10.1016/ S0309-1740(02)00123-7

Grandin, T., G. C. Smith (2004): Animal welfare and humane slaughter. Department of Animal Sciences, Colorado State University. Available at: http://www.eolss.net/sample-chapters/ c10/e5-11-06-01a.pdf

Harper, G. C., A. Makatouni (2002): Consumer perception of the organic food production and farm animal welfare. British Food Journal104(3/4/5): 287-299.doi: 10.1108/00070700210425723

Hazel, S. J., T. D. Signal, N. Taylor (2011): Can teaching veterinary and animal-science students about animal welfare affect their attitude toward animals and human-related empathy? Journal of Veterinary Medical Education 38(1), 74-83. doi: 10.3138/jvme.38.1.74

Heleski, C. R., A. G. Merting, A. J. Zanella (2004): Assessing attitudes toward farm animal welfare: a national survey of animal science faculty members. Journal of Animal Science 82(9): 2806-2814. Available at: https://www.animalsciencepublications.org/publications/jas/ pdfs/82/9/0822806

Ingenbleek, P. T. M., V. M. Immink (2011): Consumer decision-making for animal-friendly products: synthesis and implications. Animal Welfare 20(1), 11-19.

Keeling, L., V. Immink, C. Hubbard, G. Garrod, S. A. Edwards, P. Ingenbleek (2012): Designing animal welfare policies and monitoring progress. Animal welfare Journal. Vol 21(1), 95105.https://doi.org/10.7120/096272812X13345905673845

Knight, S., K. Nunskoosing, A. Vrij, J. Cheerryman (2003): Using grounded theory to examine people's attitudes towards how animals are used. Soc. Anim, 11(4), 179-198.

Knight, S., A. Vrij, J. Cheerryman, K. Nunskoosing (2004): Attitudes towards animal use and belief in animal mind. Anthrozoös: A multidisciplinary journal of the interactions of people and animals 17(1), 43-62.http://dx.doi.org/10.2752/089279304786991945

Knowless, T. (2007): European food scares and their impact on EU food policy. British Food Journal 109(1):43-67. http://dx.doi.org/10.1108/00070700710718507

Krystallis, A., M. D. De Barcellos, J. O. Kuegler, W. Verbeke, K. G. Grunert (2009): Attitudes of European citizens towards pig production systems. Livest.Sci.126(1-3),46-56. http://doi. org/10.1016/j.livsci.2009.05.016

Mayfield, L. E., R. M. Bennett, R. B. Tratner, M. J. Wooldridge (2007): Consumption of welfare-friendly food products in Great Britain, Italy and Sweden, and how it may be influenced by consumer attitudesto, and behaviour towards, animal welfare attributes. International Joumal of Sociology of Agriculture and Food 15(3), 59-73. Available at: http://www.jisaforg/contents/15-3/mayfield/index.html

Mikuš, T., B. Njari, M. Bratulić, Z. Kozačnski, L. Kozačinski (2011): Animal welfare assessment in pig abattoir. Meso 8(5), 364-367. Available at: http://hrcak.srce.hr/index. php?show=clanak\&id_clanak_jezik=120165\&lang=en

Mikuš, T., I. Petak (2010): Animal welfare and meat quality. Meso12(1): 41-44.

Miele, M., A. Evans (2005): European consumers views about farm animal welfare. In: Butterworth,A., (Ed.), Science and Society Improving Animal Welfare. Welfare quality Conference Proceedings, 17/18 November 2005. Brussels, Belgium. pp.13-29.

Moynagh, J. (2000): EU regulation and consumer demand for animal welfare. AgBioForum 3(2-3), 107-114.

Napolitano, F., A. Girolami, A. Braghieri (2010): Consumer liking and willingness to pay for high welfare animal-based products. Trends in Food Science \& Technology 21(11), 573-543. http://doi.org/10.1016/j.tifs.2010.07.012

OEJC (Official Journal of the European Communities) (28.02.2006), №. C 49: Action Plan on the Protection and Welfare of Animals

OEJC (Official Journal of the European Communities) (18.11.2009), №. L303/1: Council Regulation (EC) No 1099/2009 of 24 September 2009 on the protection of animals at the time of killing.

Ostović, M., Ž. Mesić, T. Mikuš, K. Matković, Ž. Pavičić (2015): Attitudes of veterinary students in Croatia toward farm animal welfare. Animal Welfare 25(1), 21-28. Available at: http:// www.ingentaconnect.com/contentone/ufaw/aw/2016/00000025/00000001/art00003

Paul, E. S., A. L. Podberscek (2000): Veterinary education and students' attitudes towards animal welfare. Veterinary Record 146(10), 269-272.http://dx.doi.org/10.1136/vr.146.10.269

Pollard-Williams, S., R. E. Doyle, R. Freire (2014): The influence of workplace learning on attitudes toward animal welfare in veterinary students. Journal of Veterinary Medical Education 41(3), 253-257. doi: 10.3138/jvme.0114-006R1

Sandoe, P., H. B. Simonsen (1992): Assessing animal welfare: where does science end and philosophy begin? Animal Welfare 1(4), 257-267. Available at: http://www.ingentaconnect.com/ contentone/ufaw/aw/1992/00000001/00000004/art00004

Sandoe, P., S. B. Christiansen, M. C. Appleby (2003): Farm animal welfare: the interaction of ethical questions and animal welfare science. Animal Welfare 12(4), 469-478. Available at: http://www.ingentaconnect.com/contentone/ufaw/aw/2003/00000012/00000004/art00005

Serpell, J. A. (2005): Factors influencing veterinary students' career choices and attitudes to 
animals. Journal of Veterinary Medical Education 32(4), 491-496. Available at: https://www.ncbi. nlm.nih.gov/pubmed/16421833

Spooner, J. M., C. A. Schuppli, D. Fraser (2014): Attitudes of Canadian citizens toward farm animal welfare: A qualitative study. Livestock science 163:150-158. http://doi.org/10.1016/j. livsci.2014.02.011

Stafleu, F. R., F. J. Grommers, J. Vorstenbosch (1996): Animal welfare: evolution and erosion of a moral concept. Animal Welfare 5(3), 225-234.

Tawse, J. (2010): Consumer attitudes towards farm animals and their welfare: a pig production case study. Bioscience Horizons 3(2), 156-165.https://doi.org/10.1093/biohorizons/hzq020
Veissier, I., K. K. Jensen, R. Botreau, P. Sandoe (2011): Highlighting ethical decisions underlying the scoring of animal welfare in the Welfare Quality scheme. Anim. Welf. 20(1),89-101.

Walker, J., K., N. Mcgrath, D.L. Nilsson, N.K. Waran, C.J.C. Phillips (2014): The Role of Gender in Public Perception of Whether Animals Can Experience Grief and Other Emotions Anthrozoös: A multidisciplinary journal of the interactions of people and animals. Vol 27(2), 251-266. http://dx.doi.org/10.2752/175303714X13903827487601

Winter, M., C. Fry, S.P. Carruthers (1998): European agricultural policy and farm animal welfare. Food Policy 23(3-4), 305-323.http://doi.org/10.1016/S0306-9192(98)00036-0 Dostavljeno: 3.5.2017.

Prihvaćeno: 24.5.2017.

\section{Einstellung kroatischer Fleischkonsumenten zur tierfreundlichen Aufzucht und zu tierfreundlichen Produkten}

\section{ZUSAMMENFASSUNG}

Die Entscheidungsprozesse in der Agrar- und Ernährungspolitik und Industrie hängen unter anderem von der Verbrauchermeinung ab. Das Konzept einer tierfreundlichen Aufzucht befindet sich in Kroatien am Anfang seiner Entwicklung. Darüber hinaus fehlt es an Informationen über die Einstellung kroatischer Fleischkonsumenten zu einer solchen tierfreundlichen Aufzucht und entsprechenden Produkten. Ziel dieser Untersuchung war es, Informationen über das Verhalten der Fleischkonsumenten beim Kauf von rotem Fleisch einzuholen und ihr Allgemeinwissen über die tierfreundliche Aufzucht zu prüfen. Die Einstellung der Verbraucher wurde in halbstrukturierten Interviews, Auge in Auge, unter 187 Verbrauchern in Metzgereien und auf Märkten überprüft. Die gewonnenen Daten wurden anhand einer univarianten Analyse und einem Chi-Quadrat-Test ausgewertet und mit zahlreichen Untersuchungen über den Tierschutz und verbundene Themen verglichen. Die Ergebnisse weisen darauf hin, dass das Geschlecht einen bedeutenden Einfluss aufdie Meinung über den Tierschutz hat $(P<0,05)$, während sich wohlhabendere Umfrageteilnehmer (mit höheren Einkommen pro Haushalt) auf der Relevanzgrenze $(p=0.053)$ in Bezug auf die Kaufbereitschaft von tierfreundlichen Produkten in Zukunft bewegen. Die unmittelbare Bedeutung dieser Untersuchung besteht in der Ermittlung der Einstellung kroatischer Verbraucher zu tiergerechten Produktionsverfahren und Produkten und der Prüfung ihres Wissens über das Konzept der tierfreundlichen Produktion.

Schlüsselwörter: Verbrauchereinstellung, Interview, Tierschutz, rotes Fleisch, Kroatien

\section{Actitudes del consumidor de carne en Croacia sobre los productos y producción respetuosos del bienestar animal}

\section{RESUMEN}

La toma de decisiones en el contexto de la política y de la industría agroalimentaria no puede llevarse al cabo sin incluir los actitutes del consumidor. El concepto de la cría de animales respetuosa del bienestar animal apenas empezó a desarrollarse en Croacia. Igualmente, no existe bastante información sobre los actitudes del consumidor de carne en Croacia sobre este tipo de cría y sobre los productos hechos con respecto del bienestar animal. El objetivo de este trabajo fue juntar la información sobre el comportamiento del consumidor durante la compra de carne roja y probar su conocimiento general sobra el bienestar animal en la cría de animales. Los actutudes del consumidor fueron juntados con la entrevista semiestructurada, cara a cara, en la muestra de 187 consumidores en las carnicerías y en los mercados. Los datos obtenidos fueron analizados por el análisis univariado y por la prueba chi-cuadrado y comparados con múltiples investigaciones sobre el bienestar animal y temas relacionados. Los resultados sugieren que el género (sexo) tiene influencia importante sobre la opinión sobre el bienestar animal ( $P<0,05)$, mientras los encuestados ricos (con un mayor ingreso por hogar) fueron al borde del nivel de significación ( $p=0.053$ ) en cuanto a la compra de los productos respetuosos del bienestar animal en el futuro. La contribución original de esta investigación fue determinar los actitudes del consumidor en Croacia sobre la producción y los productos respetuosos del bienestar animal y su conocimiento del concepto de la producción respetuosa del bienestar animal.

Palabras claves: actitudes del consumidor, entrevista, bienestar animal, carne roja, Croacia 


\title{
L'opinione dei consumatori croati di carne nei confronti dei proditti e della produzione da allevamento di benessere di animali
}

\begin{abstract}
SUNTO
I processidecisionali nel contesto delle politiche agroalimentari e industrialinel settore agroalimentare non possono dirsi completi senza il coinvolgimento dell'opinione dei consumatori. L'idea dell'allevamento animal friendly (ossia sensibile al benessere degli animali) è all'inizio del suo sviluppo. Non disponiamo, inoltre, di sufficienti informazioni sull'opinione dei consumatori croati di carne rispetto a questa modalità di produzione e ai prodotti ottenuti dall'allevamento animal friendly. Lo scopo di questa ricerca consiste nel raccogliere informazioni sul comportamento dei consumatori di carne all'atto dell'acquisto di carne rossa e testare le loro conoscenze generiche in fatto di allevamento animal friendly. Le opinioni dei consumatori sono state raccolte mediante un'intervista semi-strutturata, svolta faccia a faccia su un campione di 187 consumatorinelle macellerie enei mercati civici. I dati ottenuti sono stati analizzati con il metodo dell'analisi univariata e del test chi quadrato e raffrontaticon idati derivantida numerose ricercheriguardanti l'allevamento animal friendly e temi analoghi. I risultati suggeriscono che il genere (il sesso) dell'intervistato influisce significativamente sull'opinione riguardo all'allevamento animal friendly $(P<0,05)$, mentre gli intervistati più abbienti (con maggiore reddito per nucleo familiare) sono al limite del significativo $(p=0.053)$ riguardo alla propensione futura verso l'acquisto di prodotti derivanti da allevamento animal friendly. Il contributo originale di questa ricerca consiste nell'aver fatto luce sulle opinioni dei consumatori croati in ordine alla produzione e ai prodotti da allevamento animal friendly e sul loro grado di conoscenza dellidea di produzione animal friendly.
\end{abstract}

Parole chiave: opinioni dei consumatori, intervista, benessere degli animali, carni rosse, Croazia

\section{Međunarodni kongres}

\section{"Veterinarska znanost i struka"}

- Iznimno nam je zadovoljstvo pozvati Vas na međunarodni kongres "Veterinarska znanost i struka" koji će se održati 5., 6. i 7. listopada 2017. godine u prostorima Veterinarskog fakulteta Sveučilišta u Zagrebu. U okviru ovogodišnjeg kongresa po prvi će se put održati Dan doktorata na kojemu će doktorandi Veterinarskoga fakulteta predstaviti svoja istraživanja.

\section{- Pokroviteljstva:}

Predsjednica Republike Hrvatske Kolinda Grabar Kitarović

Gradonačelnik grada Zagreba Milan Bandić

\section{- VAŽNI DATUMI}

Rok za prijavu sažetaka produljen do 30. lipnja 2017. Rok za ranu prijavu produljen do 15. lipnja 2017. Rana prijava sudionika - 1. lipnja 2017. Predaja sažetaka - 12. lipnja 2017.

Obavijest o prihvaćanju sažetaka - 24. srpnja 2017. Prijava za radionice -17. srpnja 2017.

\section{- ODBORI}

Organizacijski odbor:

Predsjednik:

Zoran Vrbanac

\section{- Dopredsjednici:}

Nika Brkljača Bottegaro

Nevijo Zdolec

\section{- Članovi lokalnog organizacijskog odbora:}

Damir Agičić, Jasna Aladrović, Iva Benvin, Diana Brozić, Ivan Forgač, Anđelko Gašpar, Alen Hrastnik, Maja Lukač, Nino Maćešić, Mario Ostović, Nikica Prvanović - Babić, Lada Radin, Nevenka Rudan, Krešimir Severin, Magda Sindičić, Zrinka Štritof, Jelena Šuran, Ivana Tlak Gajger, Ivan Vlahek, Lana Vranković, Ivona Žura Žaja, Slavko Žužul

\section{- Članovi međunarodnog organizacijskog odbora:}

Sanja Aleksić-Kovačević, Tibor Bartha, Otto DoblhoffDier, Nihad Fejzić, Andrej Kirbiš, Danijela Kirovski, Vanja Krstić, Jana Mojžišova, Lazo Pendovski, Vladimir Petkov, Foteini Samartzi, Muhamed Smajlović, Breda Jakovac Strajn, Martin Tomko, Igor Ulčar, Gorazd Vengušt, Petra Winter, Petra Zrimšek

\section{- Znanstveni odbor:}

Goran Bačić, Ljubo Barbić, Željko Cvetnić, Tomislav Dobranić, Petar Džaja, Martina Đuras, Anamaria Ekert Kabalin, Željko Grabarević, Juraj Grizelj, Andrea GudanKurilj, Boris Habrun, Danijela Horvatek Tomić, Dean Konjević, Josip Kos, Josip Madić, Alemka Markotić, Dražen Matičić, Vesna Matijatko, Zoran Milas, Marko Samardžija, Alen Slavica, Nenad Turk, Romana Turk, Tatjana Vilibić-Čavlek, Ksenija Vlahović

http://www-staro.vef.unizg.hr/vzs2017/ 